\title{
NOTE ON WORDS USED BY SOUTH AMERICAN INDIANS FOR BANANA
}

BY

THOMAS E. PENARD

In his "Comparative ethnographical studies" Dr. Erland Nordenskiöld ${ }^{1}$ ) has published a table of words used by various South American Indian tribes for the Plantain (Musa paradisiaca) and the Banana (Musa sapientum). $\mathrm{He}$ calls attention to the confusion arising from the failure of collectors of vocabularies to note the distinction between the two, and the consequent difficulty of making an accurate distributional map.

Lists of words are sometimes collected at great inconvenience, and it is not always practicable to go into minute details at the time; but where possible it is of the utmost importance to be explicit in the definitions. A traveler desiring the word for "tree" may point to a certain species, and thus receive, not the general term he is after, but the name of the particular tree to which he is pointing. Investigators seek to guard against errors of this nature, but the pitfalls are many, especially when cultivated or domestic species are involved.

Thus in tracing linguistic affinities it may appear from a comparison of general terms such as "tree" that no analogy exists, whereas if the names of recognized species or varieties were known a close agreement might be shown. I am led to this conclusion in comparing words for banana used by the Indians of Surinam with those of other tribes recorded in Nordenskiöld's list.

1) Deductions suggested by the geographical distribution of some postColumbian words used by the Indians of S. America, Göteborg 1922. 
The Arawaks and the Kaliñas (Caribs) of Surinam have the following names for the banana and its varieties:

Plantain (Musa paradisiaca), Ar. platena ${ }^{\mathbf{1}}$ ) or pratana; Kal. palulu or baruru.

Banana (Musa sapientum), Ar. manikinya; Kal. palulu or baruru.

"Indian banana" (red variety), Ar. madžosiro; Kal. pomele or bomere.

"Apple banana", Ar. tomorero; Kal. mutapere or mateli.

"Plantain banana", Ar. bara bararo; Kal. asibana.

"Lady's finger”, (dwarf variety), Ar. palili; Kal. paliti.

Platena is from the Spanish plátano; and palulu is the name of the native "wild banana" (Heliconia Bihai). These names were evidently given to the plantain in postColumbian times.

The derivation of the general term manikinya is not known to me. I do not find any similar word in the list prepared by Nordenskiöld except manekuma which is cited from Schomburgk as a Macusi word. On the other hand madzosiro, the name of the red variety, is represented by mátseru of the Karútana, the "S.-Thomé-Banan" (ex Koch-Grünberg); mátseru of the Siusí, the small banana (ex Koch-Grünberg); maséru of the Baré, the small banana (ex Koch-Grünberg); and perhaps also matsāte of the Cuna-Cueva (ex Lehmann). In view of the fact that the name, in Surinam at least, is applied to the red variety, I venture to suggest that it originally came from the Portuguese matizar, "to vary the colors, to beautify", and the ending "-eiro" denoting tree as in tamarindeiro, tamarind tree.

Apparently the Kaliña word pomere was also based on the striking color of the red banana, from $p o$, to be, and mere color; but its similarity to the Spanish palmera, the date palm, is very suggestive. The Arawak name for the "Apple banana", tomorero, also bears a strong resemblan-

$\left.{ }^{2}\right)$ Orthography in accordance with system in C. H. de Goeje's Etudes inguistiques Caraïbes, Amsterdam,1909, p. 75. 
ce to the Portuguese tamareira, the date palm. But if pomere and tomorero were derived from palmera and tamareva respectively, I am at a loss to account for their application to the banana unless the name was suggested to the Europeans by the clusters of fruit.

The name bara bararo is used today for the "plantain banana", closely allied to the "Gros. Michel" variety which was raised for export. It is probably from bara, the sea, and the word banana.

Paliti, the name of the dwarf variety, appears to have been derived from the Kaliña pali, grandchild.

The negroes, with whom the Indians are in close contact, call the banana bakoeba, a word of wide distribution in South America. It may seem strange that this name did not find its way into the language of the Surinam Indians; but the latter are very slow to adopt a foreign word when their own tongue already has one that is satisfactory. It would seem therefore that palulu and manikinya were already established when the name bakoeba came into common use among the negroes of Surinam.

Arlington, Mass., U. S. A. 